\title{
Manifestations of Transphobia in Computer- Mediated Communication. A Case Study of Language Discrimination in English and Polish Internet-Mediated Discourse
}

\begin{abstract}
This article aims to investigate the linguistic means of transphobic discrimination observed on the Internet. The languages analysed are English and Polish, since they both offer their speakers direct and indirect ways that discrimination manifests itself, yet Polish seems to enable a more noticeable means because of the presence of grammatical gender in the language. The paper discusses twelve samples of Computer-Mediated Communication, using the methodological tools offered by Critical Discourse Analysis and Queer Theory. Based on the analysis of the samples, the article shows that even though transphobia lies mainly in lexical choices of the speaker, it is not always direct, i.e. visible in insults and attacks on a trans person, but is oftentimes indirect, i.e. visible in the incorrect use of personal pronouns in both English and Polish, or in the incorrect use of grammatical gender in Polish. Moreover, while transphobia visible in language is not always intended by the speaker, it can still be considered to be discriminatory.
\end{abstract}

\section{Keywords}

computer-mediated communication, discriminatory language, grammatical gender, social media, transphobia, transphobic language

\section{Streszczenie}

Artykuł ma na celu zbadanie środków językowych używanych w języku transfobicznym zaobserwowanym w internecie. Analizie poddane zostały języki angielski i polski, ponieważ obydwa umożliwiają ich użytkownikom bezpośrednie i pośrednie sposoby dyskryminowania na tle transfobicznym, język polski zdaje się jednak umożliwiać bardziej zauważalny sposób ze względu na obecny w nim rodzaj gramatyczny. W artykule omówiono dwanaście przykładów komunikacji internetowej, korzystając z metodologii krytycznej analizy dyskursu i teorii queer. Na podstawie analizy materiału empirycznego w artykule wykazano, że chociaż transofobia realizowana jest głównie poprzez wybory leksykalne danego nadawcy, nie zawsze jest ona bezpośrednia (tj. opiera się na obelgach i atakach na osobę transpłciową), lecz często bywa pośrednia (tj. polega na użyciu niewłaś- 
ciwych zaimków osobowych zarówno w języku angielskim, jak i polskim, czy też na użyciu niewłaściwego rodzaju gramatycznego w języku polskim). Ponadto pomimo że transfobia widoczna w języku nie zawsze jest zamierzona przez osobę mówiącą, wciąż może być uznana za dyskryminującą.

\section{Słowa kluczowe}

komunikacja internetowa, język dyskryminacji, rodzaj gramatyczny, media społecznościowe, transfobia, język transfobiczny

\section{Introduction}

English and Polish have different grammar systems, which, in turn, offers different ways of approaching the problem of discriminatory language. Most research on transphobia seems to focus on direct linguistic discrimination, such as derogatory terms (e.g. Bartram nd.; Hall 2015), or social injustice and wellbeing (e.g. Haas et al. 2014; Hamann 2014; Dynarski 2016; Dynarski et al. 2016). This paper attempts to show that transphobia is not always direct, i.e. realised through transphobic insults. The analysis presented in the paper aims to demonstrate how less direct transphobia is expressed in English and Polish, and it focuses on the linguistic means of discrimination against trans people which do not fall clearly into categories of negative labelling or specification, but are rather realized more indirectly, for example through the use of the incorrect grammatical gender or personal pronouns.

The methodological framework used in the analysis of twelve samples of computer-mediated communication in English and Polish comprises Critical Discourse Analysis (CDA) and Queer Theory, as they allow for detailed insight into the ways in which transphobia might be manifested in language use on the Internet.

\section{Theoretical background}

The analysis was conducted using methodological tools provided by Critical Discourse Analysis and Queer Theory. Critical Discourse Analysis is a useful tool for the exhaustive analysis of transphobic language and its consequences for a number of reasons: it is a "transdisciplinary" approach, instead of a simply "interdisciplinary" one, which means that CDA enters into "an informed dialogue" with other disciplines and theories (Fairclough 2012:1); it is "politically committed to social change" (Jørgensen and Phillips 2002: 64); it emphasises the ideological function of discourse (discursive practices lead to ideological effects understood as the "creation and reproduction of unequal power relations between social groups," Jørgensen and Phillips 2002: 63); and finally, 
it assumes that discourse, on the one hand, reflects social structures, and on the other hand, shapes and reshapes them (61). Fairclough (1989: 1, 22-28) emphasises the connection between language and power relations in society, focusing in his model for discourse analysis on three different dimensions of discourse (i.e. texts, discursive practices, and social practices) and the relations between them. Trans people, as a minority group struggling with numerous negative stereotypes and encountering a significant amount of hate speech directed at them, can easily fall victim to negative discourse practices related to them, which in turn lead to their lower status in society, as opposed to the dominant majority.

Queer Theory is a useful tool for the analysis of the transphobic language samples presented in this paper because, despite the fact that the starting point for its critical approach is sexuality, it currently analyses problems from two separate, but interrelated perspectives: sexuality and gender, while also "[providing] useful tools for linguistic research" (Livia and Hall 1997: 5-7). Moreover, Queer Theory focuses on the transgender perspective, or on any genders and sexualities which "do not meet the heteronormative ideal," (Motschenbacher and Stegu 2013: 520), which broadens the analysis of LGBTQ+ discourse from the field of same-sex to cross-sex as well, while, at the same time, taking into account sexualities different and more complex than just homosexual or heterosexual (Livia and Hall 1997: 5-7; Motschenbacher and Stegu 2013: 520-521). Finally, Queer Theory looks at historical and cultural background as well, which might provide additional information for linguistic research (Livia and Hall 1997: 10-13).

Computer-Mediated Communication can be explained as "any human communication achieved through, or with the help of, computer technology" (Thurlow et al. 2004: 15). The excerpts analysed are examples of CMC, which does not always adhere to rules that would be followed in other types of communication (such as, in the case of this article, avoidance of discriminatory language). Some of the examples were written under a nickname, while others under a given user's full name. It is often assumed that anonymity in CMC allows for a more significant defiance of standard rules of communication, such as the use of derogatory or foul language (e.g. Pavlíček 2005; Huang et al. 2015). This issue will also be a part of the analysis provided in the paper.

\subsection{Transphobia in language}

Research on the topic of transphobia in language has been limited so far, hence some of the sources cited in this section are not strictly academic. They include websites run by non-governmental organisations, professional associations, or LGBTQ+ rights activists, as well as articles in online newspapers written by transgender people discussing the subject. 
Discriminatory language aimed specifically at trans people is often referred to as 'transphobic language,' 'anti-trans language,' or 'transphobic harassment in language' (e.g. Bartram nd.; Turner et al. 2009; Wernick et al. 2014). It might be targeted at transgender people, transsexual people, and other identities on the spectrum. In her guide to tackling homophobic, biphobic and transphobic language written for the Stonewall Group, Bartram (nd.: 5) lists three ways in which transphobia might be visible in language. The first is classified as terms of abuse, i.e. referring to a trans person by means of derogatory terms, such as "tranny" or "he-she," as well as talking about them using the personal pronoun 'it' or "deliberately misnaming or misgendering them" (Bartram nd.: 5), which means using the incorrect personal pronouns when addressing a person in a conversation. The second type of transphobic harassment in language can be manifested through taunting, or inappropriate comments or questions about a trans person's gender or gender identity, e.g. questions such as Are you a boy, or a girl? and comments such as You're not a 'real' girl (ibid.). The last type listed by Bartram are questions and comments about a trans person's body, e.g. asking them what their body looks like.

Another guide dedicated to the same issue, written by members of Egale Canada Human Rights Trust suggests that some of the types of transphobia mentioned in the Stonewall Group's guide could generally be summed up as the "purposeful enforcement of cisnormativity" ([3]: 2). They explain that "[c] omments that are meant to assert that sex, biology, or genitalia, inescapably define someone's gender identity are cisnormative, and may be motivated by transphobia" (ibid.). Examples of such discrimination could include negative or teasing comments and questions about the trans person's genitals or surgery (e.g. If you were born a man, and you look like a man, then you're a man, asking what their bodies look like naked, or if they are "pre-op" or "post-op"); "forcing the gender binary on non-binary, gender queer, gender fluid, gender variant and gender non-conforming persons" (examples provided in the guide include using the personal pronoun 'it,' or questions such as What are you, a boy or a girl?); and attacking a trans person's ability to "pass" as their gender identity (the guide provides examples of statements such as You make an ugly woman or You're too pretty to be a boy) to name a few.

The Polish Fundacja RÓWNOŚĆ.INFO (see Wasiak-Radoszewski nd.) lists hate speech towards trans people among the forms of transphobic behaviour, while various organisations which are not strictly concerned with LGBTQ+

\footnotetext{
${ }^{1}$ Pre-operation or post-operation.

${ }^{2}$ The term "passing" refers to a trans person's ability to be perceived as a particular gender identity. Although it can be used with regard to various identities (e.g. passing as heterosexual), the term is usually associated with transgender people. It is, however, perceived as controversial and many trans people have strong negative emotions towards the term, as it implies some sort of "deception, dishonesty, and fraud" (Billard 2018: 1-8; Halberstam 2001: 14).
} 
issues and newspaper articles describe instances of such acts and emphasise the importance of language used towards trans people (e.g. Szewczyk 2017, [7]). Similarly, a section on Planned Parenthood's website dedicated to sexual orientation and gender describes a set of transphobic attitudes and behaviours, including (but not limited to) "disbelief or discounting preferred pronouns or gender identity" and "derogatory language and name-calling" [6].

It is crucial to clarify that an act of discrimination against a transgender person does not need to be deliberate in order to be transphobic. Wipe Out Transphobia [10] states what follows: "Whether intentional or not, both transphobia and cissexism have severe consequences for the target of the negative attitude." ${ }^{3}$ In her article for The Guardian, tackling the subject of mental health among trans people who deal with transphobia, Talusan (2015) writes:

For trans people, discrimination in various forms can literally come from anyone, from strangers to your closest family members, across all categories of identity, whether intentional or unintentional, conscious or not.

Both sources agree that transphobic behaviours do not need to be deliberate and conscious acts in order to have a negative effect on the person at whom they might be directed, and to be classified as transphobic. While numerous other sources explain why and in what ways misgendering ${ }^{4}$ trans people is harmful (e.g. Allen 2017; Bailey 2012; Dennis 2017), a number of them point out that even the unintentional use of the incorrect personal pronoun is still unjust and might have severe negative consequences on the mental health and well-being of a trans person (e.g. Clements nd.; Hope 2014; Hord 2016; St. Patrick 2017, [1], [4]). ${ }^{5}$ In the case of this article, those behaviours would be linguistic acts, mainly visible in lexical and grammatical choices of language users. The level of intentionality of the speaker's transphobic behaviour is not a part of the analysis, as the main focus is on showing linguistic means of discrimination against transgender people. Moreover, it is often not possible to judge the intention of the speaker in CMC.

${ }^{3}$ Wipe Out Transphobia is a project run by volunteers from all over the world, aimed to end transphobia in society. Cissexism (sometimes written as cis-sexism) can be defined as a set of norms, or appealing to such norms, which enforce the gender binary, that is the socially constructed belief that there exist only two genders, and gender essentialism, which is an ideology claiming that (binary) gender can only be assigned to a person based on their genitalia, and is not a social construct or a self-identity (e.g. Crompton, Lyonette 2005: 601-603, 617-618; Ferguson 2014).

${ }^{4}$ Misgendering is a term used to describe an act of intentional or unintentional referring to or describing a person with the use of language that does not correspond with their gender identity, such as using the incorrect personal pronouns (Clements [nd.]).

${ }^{5}$ Many of the sources base their arguments and research approach on their own experience as a transgender individual, or on transgender narratives of scholars and activists (e.g. Hord 2016: 2-4 provides a number of such examples collected in their article). 
One of the main assumptions in this paper is that Polish enables more conspicuous ways of discriminating against transgender people than English because it has grammatical and not natural gender. Grammatical gender is visible in nouns, adjectives, pronouns, numerals, and verbs, and since grammatical agreement is required in the language, in some situations gender is highly visible in a given sentence. This provides additional options of using discriminatory language targeted at transgender people in a less direct, yet still harmful way, such as referring to a trans person using the incorrect grammatical gender (e.g. zrobit 'did 3 SG.MASC' instead of zrobiła 'did 3 SG.FEM' when referring to a transsexual woman). The analysis of the Polish examples provided in the paper attempts to show how this additional means of discrimination against trans people can work.

\section{Methodology}

The analysis presented here is based on twelve samples collected from comment sections under videos posted on YouTube as well as from articles found on news sites along with user-generated content from their comment sections. The videos were short documentaries featuring Laverne Cox, who is an actor and an activist, or were music videos by the artist Anohni. The articles discussed Anna Grodzka, who is a Polish politician and was the first openly transgender Member of Parliament in Poland. All of the three people are publicly known to be transgender women and thus different attitudes towards them are expressed in CMC both by the authors of the articles and the commenters quoted in the samples analysed in the paper. The samples differ in length as some of them are discussions between commenters, while some are single comments which did not meet with any response. Links to all the sources of the analysed samples can be found in the Source section in the References.

The four strategies of transphobic discrimination via the means of language identified in the samples were chosen based on those described by scholars and trans rights activists (see Section 2.1), and are as follows:

- terms of abuse (the use of derogatory terms, or the personal pronoun 'it'),

- discounting the gender identity of the trans person in question (misgendering them, the use of their deadname, ${ }^{6}$ or the use of incorrect grammatical gender in Polish verbs, adjectives, etc.),

${ }^{6}$ 'Deadname' is the name of a transgender person from before their transition, or in other words, their "given name" or "birth name" (although the latter two are terms that many trans people avoid). See e.g. Clements 2017, Butler 2018, Chiu 2018). 
- asserting that someone's gender identity is dictated by biology (comments about their bodies enforcing the gender binary, comments about their genitals, attacking their ability to "pass"),

- dehumanising the trans person in question (equating them with animals or objects, the use of the grammatically neuter gender).

The excerpts are samples of online content written by English-speaking (6 samples) and Polish Internet users ( 6 samples), presented in order from the least to the most direct instances of transphobia in each language (instead of, for example, according to discrimination strategies), since most of the cases serve as examples of more than one type of discrimination. The excerpts are divided into two subsections according to the language they were written in. Each subsection is described separately and the strategies are pointed out. Finally, conclusions for each section as well as for the twelve samples altogether are drawn.

\section{Discussion of the samples}

A considerable part of public and political discourse regarding transgender people in both English and Polish is comprised of erasing them from society and various forms of denigration. The language used by public figures, such as politicians and journalists, can be regarded as both a source of transphobic attitudes observable within society and an instrument which reinforces them further. Such attitudes, as will be shown in the following sections, can include disrespecting transgender people and their gender identities, negating their existence in society, presenting them as mentally ill, and assuming that gender is binary and solely based on biology (e.g. Anderson 2018; Lubnauer 2015, [5], [8], [9]).

As explained in Section 3, the discussion is divided into two parts, according to the language in which the analysed samples were written. First, the English examples will be discussed. Examples 1-2 come from the comment sections on YouTube under music videos by the artist Anohni, who is an openly transgender woman, formerly known as Antony of the music group Antony and the Johnsons. ${ }^{7}$ Examples 3-6 come from the comment sections on the same website under short documentaries about Laverne Cox, who is an openly transgender woman, actor and LGBT rights advocate. ${ }^{8}$ The original spelling was preserved in all of the samples. The use of square brackets with some of the user names means that they were tagged by their interlocutor in order to respond to their comment directly. Underscore is used to point the parts of the excerpts which were identified as transphobic and discussed in the paper.

\footnotetext{
${ }^{7}$ See, e.g. Beaumont-Thomas (2016); Pareles (2016), and Reynolds (2016).

${ }^{8}$ See Cox (nd.).
} 


\subsection{English samples}

\section{Example 1 [S5]}

User $01 \mathrm{E}$ the voice sounds like a male voice!

User 02E it is a male she is Naomi Campbell she's famous she's just playing a part

User 03E [User 02E] Female actually.

User $01 \mathrm{E}$ female with a male voice so weird!

User 03E [User 01E] She's transgender.

User 04E [User 03E] Naomi is? woah.. I didn't know that

User 05E [User 04E] not Naomi. The singer ANOHNI

User $06 \mathrm{E}$ Anohni is a transgender singer. Naomi only lypsincs her voice.

User $06 \mathrm{E}$ Anohni is a transgender singer.

User 02E i didn't realise he was transgender thank you for clearing it up $=\mathrm{D}$

User 04E [User 05E] oooh, okay

User 07E The girl on the video is Naomi, Anohni is a transgender singer

User $08 \mathrm{E}^{\star}$ she. :)

User 09E Anohni goes with female pronouns.

User 10E dude, seriously?

User $11 \mathrm{E}$ is not male, is a trans person.

Example 2 [S5]

User 12E I love your voice..amazing...wonderfull..perfect...

User 02E listen to his other stuff under the name "Anthony and the jOHNSONS"

User 13E ^her

User 14E [User 02E] her*

User 15E [User 12E] No

User 16E You might like Antony too. His voice is just like hers.

User $17 \mathrm{E} i$ thought in the beginning listening to that song that Anthony was singing ..her voice is almost the same with him.and i still prefer Anthony and the johnsons

User $18 \mathrm{E}$ it is antony - she now identifies as her female name anohni

Example 3 [S6]

User 19E I love Laverne she's such an inspiration.

User 20E [User 19E] *he

User 21E [User 20E] ${ }^{\star}$ she

User 22E [User 20E] U R ANOTHER EXAMPLE OF IGNORANCE .... UGLINESS... OUCH! YOUR STUPID STAGE NAME IT STICKS SO WELL.

Example 4 [S5]

User 23E No one would watch if Anohni was actually featured in hisher video, he's ugly af!

Example 5 [S7]

User 24E Can't change your DNA.

User 25E Clearly your researching skilld aren't up to date.

User 26E [User 25E] clearly your english isnt up to date either

User 27E [User 25E] he's still a dude.

User 28E Chick with BBC 
User 29E How did he become famous

User 28E [User 29E] Chick with BBC

User 29E [User 28E] that's not a chick though that's a man

User 30E This man looks cool [emoticon of a smiley face wearing sunglasses]

User 31E [User 30E] yes she's a cool and classy lady and famous too

User 28E Chick with BBC

Example 6 [S6]

User 32E Laverne Cox bleached ${ }^{9}$ the fuck out of his skin. I guess he thinks lightening his skin makes him more feminine.

User 33E maybe you should drink some bleach

User 32E [User 33E] There's none left, Laverne used it all.

User $34 \mathrm{E}$ lol we get it sweetheart, nice try laverne is never gonna see your attempts at an insult

User 32E [User 34E] It's not an insult if it's true. Google "Laverne Cox bleaching" $\mathrm{He}$ used to have a much darker complexion.

User 35E [User 32E] her

User 35E [User 32E] she

Altogether, 21 instances of transphobia were identified in the English samples. Strategies of such discrimination manifested in the examples fall into the categories of terms of abuse ( 1 instance), discounting the gender identity of the trans person in question (13 instances by 9 different users), and asserting that someone's gender identity is dictated by biology ( 7 instances by 5 different users). No instances of dehumanising the trans person in question by equating them with animals or objects are present in the samples.

All of the 6 samples presented above are examples of the incorrect use of personal pronouns. Examples 1 and 2 are instances of indirect and non-deliberate transphobia visible in the use of incorrect personal and possessive pronouns, which, as explained in Section 2.1, can still be considered discriminatory and harmful by transgender people. In Examples 1 and 2, the authors of such posts are corrected by other users, which can serve as evidence for different attitudes towards trans people and potentially transphobic behaviours.

Examples 1 and 2 are clear cases of a lack of knowledge about the gender identity of the trans person in question (e.g. User 02E in Example 1 still uses the incorrect, masculine personal pronoun after learning that the artist is a transgender woman, which is a case of disregarding the trans person's preferred personal pronouns and discounting their identity). Users $16 \mathrm{E}$ and $17 \mathrm{E}$ in Example 2 use Anohni's deadname. However, the fact that it was a part of the artist's former band name, Antony and the Johnsons, can be the reason behind referring to her with the wrong name. Additionally, Example 1 seems to be an instance of misunderstanding between the commenters, which is common in computer-mediated communication. Towards the end of the exchange,

\footnotetext{
${ }^{9}$ Boldface in the original comment.
} 
the platform users manage to provide one another with the correct information about Anohni's gender identity.

Example 3 is an interesting case, since it is not a transphobic poster (User $20 \mathrm{E}$, who introduces the incorrect personal pronoun he with an asterisk, used in CMC to signify correcting a mistake) who is displaying aggression towards their interlocutor or the trans person in question, but the other poster (User 22E) defending Laverne Cox, as visible in their use of capital letters throughout the whole comment and the use of derogatory language.

Examples 3-6 are instances of direct and deliberate transphobia. In Example 4, User 23E uses the incorrect, masculine personal pronoun when speaking about Anohni, preceded by the clearly transphobic, conjoined possessive pronoun hisher, which falls clearly under the category of terms of abuse. User 23E's comment about the artist's attractiveness could be interpreted as an attack on her ability to "pass" as a woman, as they call her ugly af.

Finally, in Examples 5 and 6, User 28E and User 32E's comments are openly transphobic, as visible in their use of the incorrect personal and possessive pronouns and profanities (Laverne Cox bleached ${ }^{10}$ the fuck out of his skin) or referring to her as a man and $a$ dude. The two users' comments are also racist, as visible in their suggestions about Cox lightening his skin in order to appear more feminine (User 32E) and referring to her as a chick with $B B C$ three times in separate discussions by the same user (28E). ${ }^{11}$ Example 5 shows transphobia visible in the clear denial of the trans person's identity, and in comments and assumptions about her genitals. Such comments also assert that a person's gender is dictated by biology (their genitals). In this case both transphobia and racism of the user relate to the trans person's body, and are both deeply rooted in stereotypes of sex and race, the latter connected with the fantasy about the "excessive sexual appetites and prowess of black men" (Hall 1997: 230-231, 262-263).

\subsubsection{Discussion of the English samples}

Examples 1-6 demonstrate two instances of what appears to be unintended transphobia resulting from the users' lack of knowledge, and four instances of the deliberate use of transphobic language, both visible mostly in choosing the incorrect personal and possessive pronouns, and in referring to the trans person in question by their deadname. Some of the excerpts are examples of rare cases of attacks on the trans person's characteristics which are unrelated to their gender identity or expression (two instances), and disregard for or unawareness of the fact that the person in question is transsexual or transgender. The predominant strategy of transphobic discrimination visible in the English

\footnotetext{
${ }^{10}$ Boldface in the original.

11 ' $\mathrm{BBC}$ ' in this context is used as a slang abbreviation which stands for "big black cock" (“BBC”, 2017).
} 
samples was discounting the gender identity of the trans person in question (13 instances).

Moreover, out of all 35 users quoted in examples above, 15 used only nicknames with their posts, while 20 used their full names. Five of the non-anonymous users conveyed strong prejudice against transgender people. This shows that in some cases anonymity on the Internet is not a substantial factor in CMC when expressing strong, negative views and displaying discriminatory attitudes.

\subsection{Polish samples}

In this section, the Polish samples will be discussed. The excerpts come from an article about the transgender artist Anohni on a news website and the comment section under it, as well as from comment sections under articles about Anna Grodzka, concerned with her political past as a member of the PZPR (Polish United Workers' Party) political party. ${ }^{12}$ The original spelling was preserved in all of the examples. Whenever the form they/their appears in the square brackets in the translations of the Polish excerpts, it means that the grammatical gender was not present in the original form, but needed to be added in the English translation because of the differences between Polish and English grammar.

\section{Example 7 [S2]}

Anohni przedstawia “4 Degrees"

Anohni, czyli Antony Hegarty, opublikował nowe nagranie.

Utwór promuje album "Hopelessness". (...) - Ta płyta różni się od poprzednich - przekonuje artysta. (...)

Ostatni album Amerykanina, "Swanlights", zrealizowany pod szyldem Antony and the Johnsons, miał premierę w październiku 2010 roku.

User 01P Antony chcę, żeby w stosunku do jego osoby używać żeńskich form

Translation of Example 7

Anohni presents "4 Degrees"

Anohni, that is Antony Hegarty, has published [masc.] a new song.

The song is promoting the album "Hopelessness." (...) - This album is different from the previous ones - claims the artist [masc.].

The last album by the American [masc.], "Swanlights," recorded under the name of Antony and the Johnsons, had its premiere in October 2010.

User 01P Antony wishes that female forms were used with reference to [him].

\section{Example 8 [S4]}

User 02P A co was, kurczę, obchodzi, jaką miała płeć w przeszłości i jak wygląda? Skoro lepiej się czuje w skórze kobiety, to ma prawo funkcjonować jako kobieta. To w ogóle nieważne! Ważne jest, jakim politykiem jest obecnie i co ma do zaproponowania. A jest

${ }^{12}$ PZPR (Polska Zjednoczona Partia Robotnicza) was a Polish communist party modelled on the Communist Party of the Soviet Union, and governing Poland from 1948 to 1989 (Kondracki et al. 2019, Government and Society section, para. 6). 
politykiem wyjątkowym w Polsce (a raczej: polityczką). Ideową, rozumiejącą prawdziwe wyzwania, uprawiającą politykę nie dla kariery. Brawo dla Anki.

User 03P a ty kobieto moze masz $\underline{z}$ tyms do czynienia w zyciu prywatnym ze tak to cos bronisz (...)

User 03P [User 02P] chcialabys zeby takie cos było wzorem dla przyszlych pokolen nie przesadzaj

Translation Example 8

User 02P Damn, what does it matter to you [pl.] what her gender/sex was in the past and what [they] look like? If [they] feel better in a woman's skin, then [they] have the right to function as a woman. It does not matter at all! What matters is what kind of $\underline{\text { a politician }}_{\text {MASC }}$ [they] currently are and what [they] have to offer. And [they] are an

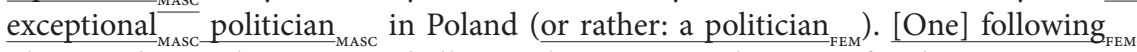
ideas, understanding ${ }_{\mathrm{FEM}}$ true challenges, being $\underline{\mathrm{FEM}}_{\text {in }}$ in politics not for the career. Bravo to Annie.

User 03P and you woman maybe have something to do with this thing $\mathrm{NEU}_{\text {in }}$ private life since you are defending it so hard (...)

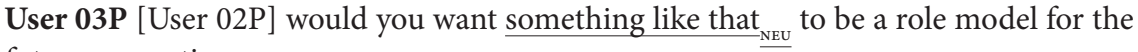
future generations come on

Example 9 [S1]

User 04P krzysiek daj spokój idz do lekarza przestan brac te tabletki i zacznij przyjmowac własciwe

User 05P anna dalej jest przystojy !!!!!!!! a ostatnio Kumorowski dokonał najwiekszego osiagniecia w swojej karierze ZGOLIŁ WASA i nikt o tym nie pisze :(

Translation of Example 9

User 04P krzysiek leave it go see a doctor stop taking those pills and start taking the right ones

User 05P anna is still handsome [masc.] !!!!!!!! and lately Kumorowski [distortion of the last name of Bronisław Komorowski, the President of Poland at the time - M.D.] made the greatest achievement of his career he SHAVED OFF HIS MUSTACHE and no one is writing about that: (

Example 10 [S4]

User 06P (...)

Powiem inaczej ...czy to ma na imię Anna, Krzysztof, Zeułnobia, Filistyna, Bartek, Brutus ..

To w ramach eksperymentu poszedłym to Łóżka z tym Czymś

Przekonać się jak się z czymś takim RU*a a potem bym to opisał w książce „Tajemnice łóżka Anny" ....

Wszak jakieś potrzeby to ma w tym seksualne a dla dobra „nauki i dla wiedzy dla potomności” byłbym skłonny się poświęcić za drobną opłatą na taki szalony eksperyment ...

Nauka kosztuje ...są jacyś chętny sponsorzy / sponsorki / firmy sponsorujące ... czas to pieniądz a Anna/Krzysztof alians jak mu tam dali ..nie młodnieje ..koszty więc rosną $\mathrm{z}$ biegiem czasu ....

Eksperymentator dla dobra ludzkości oraz potomności 
Translation of Example 10

User 06P (...)

Let me put it like that ... whether its name is Anna, Krzysztof, Zeułnobia , Filistyna, Bartek, Brutus ..

As an experiment I would go to Bed with this Thing

To find out what it's like to $\mathrm{f}^{\star} \mathrm{ck}$ a thing like that and then I'd describe it in a book The Secrets of Anna's bed ....

Certainly, it has some needs to fulfil sexual ones included and for the good of "science and for knowledge for posterity" I would be willing to sacrifice myself and conduct such an experiment for a small pay ...

Science costs ... are there any willing sponsors [masc.] / sponsors [fem.] / sponsoring companies ... time is money and Anna/Krzysztof whatever alias they gave him ..is not getting any younger ..and so the costs keep rising with time ....

Experimenter for the good of mankind and posterity

Example $11[\mathrm{~S} 3]$

User 07P Patrząc na te zdjęcia $\mathrm{z}$ jego młodości (100 procentowy męski zarost) to niewątpliwie wówczas żadnych ciągot $\mathrm{w}$ kierunku transformacji własnej płci na przeciwną raczej nie miał. Dziwne jest to, a może całkiem naturalne, że czas pojawienia się chęci zmiany płci przypada na czas wprowadzenia tych wszystkich ideologii dotyczących homoseksualistów, tranzwestytów, adopcji dzieci przez w/w. Tak mi się wydaje, że ten osobnik to tylko polityczny aktor, który cały czas ma właściwe mężczyźnie narządy płciowe, w głowie również jest 100\%-towym mężczyzną. On ma tylko takie zadanie, to jest umożliwić i ułatwić w miarę szybkie wprowadzenie w/w ogłupiających Polaków ideologii w prawo polskie jako uniwersalne normy europejskie. Bez homoseksualistów, transwestytów, lesbijek itd. nie ma mowy o wprowadzeniu jakichkolwiek praw regulujących ich życie - skoro takich ludzi brak! Tak więc jego rola sprowadza się do tego aby publicznie świadczyć o tym, że takie osoby są i że on jest tego przykładem. Myślę, że on i cała sprawa z nim związana to tylko wielka mistyfikacja służb specjalnych. Nic więcej.

\section{Translation of Example 11}

User 07P From looking at those photographs from his youth (a hundred percent male facial hair) it is clear that back then [he] didn't have any leanings towards transforming [their] own gender/sex to the opposite one. What is weird, or maybe completely natural, is that the time of the intention to undergo gender/sex change coincides with the time when all those ideologies about homosexuals, transvestites, and child adoption by those above were implemented. It seems to me that this person/specimen is but a political actor [masc.] who [masc.] still has genitals characteristic of a man, and in [their] head is still a hundred percent man. He only has this task, the task of making it possible and easy to quickly implement the ideologies mentioned above, stupefying Poles, into the Polish law and universal European norms. Without homosexuals, transvestites, lesbians, etc. there is no chance of implementing any laws regulating their lives - if there are no such people! So then his role is basically being a public proof of such people's existence and that he is an example of that. I think that he and this whole deal connected with him is just a huge mystification by the special service. Nothing more. 


\section{Example 12 [S1]}

User 08P Osoba Grodzka jest idealnym przukładem tragikomizmu w polskiej polityce. Ponieważ i tak nie wiadomo czy się śmiać czy płakać, osoba Grodzka jako ikona symbolizująca sejm, powinna zostać nie tylko v-ce, ale pełnym marszałkiem. Sejmowi się to należy.

User 09P [User 08P] to będzie całkowity upadek wszystkiego co nas odróżnia od zwierząt KrzysiekzAnną wsejmie v-ce marszałkiem wracajmy na drzewa nawet zwierzęta się nieokaleczają ach to łona SLD narodziło się to coś teraz rozumiem Millera ma naprawdę osiągnięcia na skalę światową .Co w świecie myślą o Polakach boję się pytać

User 10P [User 08P] Pójdę dalej w tym klimacie. To coś powinno zostać nawet laską marszałkowską. Razem z Kopacz stanowili by wspaniały duet. Kopaczowej z taką laska w dłoni nikt by nie podskoczył.

Translation of Example 12

User 08P [The] Grodzka person is the best example of tragicomicality in Polish politics. Because no one knows if it is best to laugh or cry here, [the] Grodzka person as an icon who symbolises the Sejm should not only become the vice, but a full Speaker of the Sejm. The Sejm deserves it.

User 09P [User 08P] it will be a complete downfall of everything which separates/ distinguishes us from animals KrzysiekwithAnna in the Sejm as vice Speaker let's get back up on trees even animals do not self-mutilate oh it was the SLD [Democratic Left Alliance, a Polish political party - M.D.] wombs from where this thing was born [neu.] now I understand Miller [Leszek Miller, leader of the SLD at the time - M.D.] he really does have achievements on a global scale. What the world thinks of the Poles I fear to ask

User 10P [User 08P] I will go further with this topic. This thing should [neu.] even become the Speaker's baton. Together with Kopacz [Ewa Kopacz, Polish prime minister at the time - M.D.] they would make a grand duo. No one would mess with Kopacz with such a baton in her hand.

Altogether, 46 instances of transphobia were identified in the Polish samples. Strategies of such discrimination manifested in the examples fall into the categories of terms of abuse (13 instances by 6 different users), discounting the gender identity of the trans person in question ( 17 instances by 8 different users), asserting that someone's gender identity is dictated by biology ( 4 instances by 2 different users), and dehumanising the trans person in question (12 instances by 5 different users).

All of the 6 samples shown above are examples of transphobic use of the incorrect personal and possessive pronouns. Out of these, 1 sample is an example of indirect and non-deliberate transphobia (Example 7), while 5 are examples of direct and deliberate transphobia. Example 7 is an instance where the author seems to be unaware of Anohni's gender identity, and uses the incorrect grammatical gender when referring to her (opublikowat ['released 3 SG.MASC'] cf. opublikowała 3 SG.FEM, Amerykanina ['(the) American'sSG.MASC.GEN'], artysta ['artistSG.MASC'] - cf. artystkaSG.FEM), as well as her deadname. 
What is interesting, in Example 7 User 01P posts a comment explaining that the musician wishes to be referred to with feminine personal pronoun but they still use the artist's deadname, and a masculine possessive pronoun jego ('his' cf. jej ['hers']), discounting her gender identity.

Examples 8-12 concern Anna Grodzka, who is a transgender woman. In Example 9, User 04 suggests that Grodzka should cure herself (idz do lekarza przestan brac te tabletki i zacznij przyjmowac własciwe - 'go see a doctor stop taking those pills and start taking the right ones'), while using a diminutive of the politician's deadname (Krzysiek instead of the full first name Krzysztof), showing a lack of respect towards Grodzka, as well as direct transphobia, implying that the fact that she is transgender might require medical treatment. The assertion that being transgender is a mental health disorder is a common form of transphobia, even though, according to The World Health Organisation, it is not classified as such [11]. User 05P's comment appears to be meant as funny or provocative: they describe Grodzka with the (misspelt) grammatically masculine adjective przystojy ('handsomeSG.MASC.NOM' - cf. przystojnaSG.MASC.NOM) even though they refer to her with the correct, feminine name Anna at the beginning of the sentence - possibly in order to ridicule her gender identity by juxtaposing a feminine name with a grammatically masculine adjective.

In Example 8, User 02P defends Grodzka after a series of negative comments from other users (not quoted in this article), but meets with a backlash from User 03P who, in both of their comments, refers to the politician as it (takie coś, tym czymś, to coś ['such a thing'/'this thing']), attacking Grodzka's gender identity in a direct way, equating her with an object and thus dehumanising her.

Examples 10-12 are instances of the most direct and deliberate transphobia presented in this paper. The quoted commenters use the incorrect personal and possessive pronouns, incorrect grammatical gender, and Grodzka's deadname throughout all of the comments. In Example 12 Users 08P, 09P, and $10 \mathrm{P}$ refer to the politician using the neuter personal pronoun to ('it'), and the word coś (tym czymś, czymś takim - 'this thing [instrumental case],' 'a thing like that [instrumental case],' to coś ['this thing']). Moreover, Users 09P and $10 \mathrm{P}$ conjugate the verbs narodzić się and powinno się in grammatically neuter forms (narodziło się - 'was born3SG.NEU', powinno - 'should 3 SG.NEU'), which dehumanises the politician even further. Moreover, User 09P states that Grodzka's presence in the Polish Sejm would mean 'the total end of everything that separates us from animals' (całkowity upadek wszystkiego co nas odróżnia od zwierzat) and thus we should all 'get back up on trees', (wracajmy na drze$w a$ ), and claims that 'even animals do not self-mutilate' (nawet zwierzęta się nieokaleczaja [sic]), by which they equate Grodzka with an animal and suggest that she is a symbol of the devolution of the human race. User 09P uses 
a transphobic hybrid of the politician's deadname and her chosen name, with the former one in the diminutive form (KrzysiekzAnna - 'KrzysiekwithAnna').

In Example 10, apart from the use of the neuter grammatical gender when referring to the politician, User $06 \mathrm{P}$ even goes as far as to attack Grodzka by offering to have sex with her as an experiment ( $w$ ramach eksperymentu poszedłym do Łóżka z tym Czymś [sic.] - 'I would go to bed with that thing as an experiment;' Przekonać się jak się jak się z czymś takim $R U^{\star} a$ [sic.] - 'to find out what it is like to $\mathrm{f}^{\star} \mathrm{ck}$ a thing like that') which, according to them, would serve scientific purposes and better mankind (dla dobra "nauki i dla wiedzy dla potomności" - 'for the good of "science and for knowledge for posterity";' Eksperymentator dla dobra ludzkości oraz potomności - 'Experimenter for the good of mankind and posterity').

In Example 11 User 07P refers to Grodzka with the masculine personal and possessive pronouns (on, $[z]$ nim, jego - 'he,' '[with] him [instrumental case],' 'his'), and calls Grodzka ten osobnik, which can be translated as 'this [male] person', with clearly negative connotations and notable distance between the commenter and the politician. The word is often used in a context related to animals, meaning 'this [male] specimen,' which would add further negative implications, thereby dehumanising Grodzka. Moreover, User 07P uses one verb declined for gender into a masculine form, nie miat ('did not have3SG.MASC'), when writing about Grodzka, which is a less direct example of transphobia than the ones analysed above, realised through the Polish grammatical gender. Lastly, User 07P comments Grodzka's facial hair on her old photographs from before her transition, and makes assertions about her genitals, which are examples of very direct transphobia, visible in the claim that biology defines one's gender and in the attack on Grodzka's ability to "pass" as a woman.

Finally, in Example 12 User 08P calls the politician osoba Grodzka ("[the] Grodzka person'). It can be argued that this sounds dehumanising, due to the intentional avoidance of the use of grammatical gender altogether in reference to Grodzka on the part of the commenter, which implies they do not accept the politician's gender identity. This also noticeably distances the commenter from the person in question.

\subsubsection{Discussion of the Polish samples}

Examples 7-12 demonstrate the deliberate use of transphobic language visible in the choice of the incorrect personal and possessive pronouns and referring to the trans person in question by their deadname. An additional way of discriminating against the trans people in question is clearly visible in the use of the incorrect grammatical gender, not compatible with the person's gender identity, such as speaking about them with the use of the masculine grammatical gender instead of the feminine one. Moreover, in some of the examples, the trans 
person in question is equated with animals or objects through the use of the neuter grammatical gender and certain lexical choices, such as referring to that person as 'a thing' (coś). Some of the examples also include referring to or addressing the trans person by their first name and/or with the diminutive of their first name, as well as commenting on the trans person's body features or genitals. The former serves as an example of a deliberate demonstration of lack of respect towards the person, and the latter as an example of very direct transphobia, falling into the category of asserting that someone's gender identity is dictated by biology.

The predominant strategy of transphobic discrimination visible in the Polish samples, similarly to the English samples, was discounting the gender identity of the trans person in question. However, the number of instances falling into this strategy (17 instances) was followed closely by terms of abuse (13 instances) and dehumanising the trans person in question (12 instances), the latter of which was absent altogether from the English samples.

All of the 10 users in Examples 7-12 used nicknames, which does not serve as evidence for the assumption that anonymity does not necessarily play a considerable role in computer-mediated communication.

\section{Conclusion}

Based on the twelve examples analysed in this paper, transphobia is not always expressed directly in language. It does not necessarily manifest itself through the use of pejorative language and insults directed at transsexual and transgender people, but can be expressed with other, less outright linguistic means, such as the incorrect use of grammatical gender or personal pronouns which disregard the gender identity of a trans person. Altogether, 46 instances of both direct and indirect transphobia were identified in the paper: 21 in the English samples and 46 in the Polish samples. Furthermore, the material collected shows that both languages have similar means of conveying less direct linguistic discrimination. The main difference between the English and the Polish samples lies in the fact that the latter includes a way of discriminating against trans people absent from the former: the use of the incorrect grammatical gender. The transphobic language of the Polish users is characterised by a more visible way of discrimination absent from English, as grammatically gendered forms of verbs and adjectives are not a part of the English grammatical system. The 6 Polish samples contain 19 instances of grammatically gendered forms visible in verb forms and adjectives, absent from English. 15 out of the 19 instances can be considered transphobic, as only 4 of them are examples of the use of the correct, grammatically feminine forms (User 02P in Example 8). 
Another observation which arises from the analysis of the examples presented in the paper is that Polish-speaking users appear to be more aggressive towards the trans person in question, which is visible in their strongly transphobic attitudes, manifested in equating transgender people with animals and objects, discounting their gender identity and attacking their ability to "pass", and even sexual advances in one case.

The anonymity offered by YouTube to its users allows them to write freely and spontaneously, often with no regard for political correctness. It is worth noting, however, that the website allows its users to link all their Google accounts, including Gmail and Google+, and thus use their real names in all platforms owned by Google. While all users in the Polish samples analysed in this paper remained anonymous, as many as 15 out of 35 commenters in the English samples used their full names. This could suggest that in some cases users of social media platforms no longer feel a strong need to hide behind nicknames and remain anonymous on the Internet, even when expressing their opinions, oftentimes with the heavy use of discriminatory language.

The strategies of discrimination against transgender people described in this paper can serve as evidence of the existence of discourse which creates an unequal power balance in society through marginalising transgender people, discounting their gender identity, and even referring to them as if they were not human.

While the ways of indirect discrimination against trans people via the means of language pointed out in this paper may not appear to be as strong, negative, and harmful as the direct ones, they should not be disregarded, and more research in the area should follow.

\section{References}

\section{Sources}

[S1] Anna Grodzka była przystojnym facetem (2013).

[http://wiadomosci.wp.pl/anna-grodzka-byla-przystojnym-facetem-60315 83404336257a?ticaid=1189d4; accessed December 17, 2017]

[S2] Anohni przedstawia „4 Degrees” (2015).

[http://muzyka.onet.pl/alternatywa/anohni-przedstawia-4-degrees/dkcpfq; accessed March 29, 2017].

[S3] Co łączy wrażliwą Annę Grodzką z byłym działaczem PZPR Krzysztofem Bęgowskim? Wszystko! (2012).

[http://wpolityce.pl/polityka/135619-co-laczy-wrazliwa-anne-grodzka-z-bylymdzialaczem-pzpr-krzysztofem-begowskim-wszystko; accessed December 17, 2017].

[S4] Pierwsza twarz Anny Grodzkiej. Wielkie fałszerstwo życiorysu działacza PZPR (2012).

[http://oszustwo.eu/archives/1742; accessed December 25, 2017]. 
[S5] Anohni "Drone Bomb Me"

[https://www.youtube.com/watch?v=aUEoic7ro_o; accessed December 18, 2017].

[S6] Laverne Cox Presents: 'The T Word' Full Documentary| MTV

[https://www.youtube.com/watch?v=mDy0DhfuxfI; accessed April 3, 2017].

[S7] Laverne Cox Explains Her Relationship With Her Body \& Struggles to Pay Rent | Body Stories | SELF

[https://www.youtube.com/watch?v=z-ylx6vhiZc; accessed 20 March, 2019].

[1] ACON. A Language Guide: Trans and Gender Diverse Inclusion.

[https://www.acon.org.au/wp-content/uploads/2018/01/External_LanguageGuide-17396_print_V13.pdf; accessed March 25, 2019].

[2] “BBC" (2017). Urban Dictionary.

[https://www.urbandictionary.com/define.php?term=BBC; accessed March 21, 2019].

[3] Egale Canada Human Rights Trust (nd.). What Constitutes Transphobic and Cisnormative Bullying and Harassment.

[https://www.ed.gov.nl.ca/edu/k12/safeandcaring/pdf/Transphobic_Cisnormative_Bullying_Harassment.pdf; accessed March 21, 2019].

[4] How to React After Accidentally Misgendering Someone (2014).

[http://www.pdxqcenter.org/how-to-react-after-accidentally-misgenderingsomeone/; accessed March 21, 2019].

[5] Pawłowicz o Grodzkiej: Jaka pani? Twarz boksera (2013).

[https://www.tvn24.pl/wiadomosci-z-kraju,3/pawlowicz-o-grodzkiej-jaka-pani-twarz-boksera,303037.html; accessed May 20, 2019].

[6] Planned Parenthood (nd.). Sexual Orientation and Gender.

[https://www.plannedparenthood.org/learn/sexual-orientation-gender; accessed March 23, 2019].

[7] Polskie Towarzystwo Seksuologiczne (nd.). Stanowisko PTS ws sytuacji społecznej, zdrowotnej i prawnej osób transpłciowych.

[http://pts-seksuologia.pl/sites/strona/83/stanowisko-pts-ws-sytuacji-spolecznej-zdrowotnej-i-prawnej-osob-transplciowych; accessed March 23, 2019].

[8] Senat.gov.pl. Debata o ustawie o uzgodnieniu płci. Senator PiS zrównuje transseksualizm z pedofilią. “Taka jest logika tego działania” (2015).

[http://wyborcza.pl/10,82983,18488441, debata-o-ustawie-o-uzgodnieniu-plcisenator-pis-zrownuje.html; accessed May 20, 2019].

[9] Trans troops return to era of 'don't ask, don't tell' as Trump policy takes effect (2019).

[https://www.theguardian.com/us-news/2019/apr/12/transgender-ban-military-trump-take-effect-dont-ask-dont-tell; accessed May 20, 2019].

[10] Wipe Out Transphobia (nd.). Transphobia.

[http://www.wipeouttransphobia.com/support/; accessed November 11, 2018].

[11] World Health Organisation moves to end classifying trans identities as mental illness (2018).

[https://tgeu.org/world-health-organisation-moves-to-end-classifying-transidentities-as-mental-illness/; accessed March 24, 2019]. 


\section{Critical literature}

BILlard Thomas J. (2018). "Passing" and the politics of deception: Transgender bodies, cisgender aesthetics, and the policing of inconspicuous marginal identities. In The Palgrave Handbook of Deceptive Communication, Tony Docan-Morgan (ed.), 463-477. Palgrave Macmillan: New York.

Crompton Rosemary, Lyonette Clare (2005). The new gender essentialism - domestic and family 'choices' and their relation to attitudes. The British Journal of Sociology 56(4), 601-620.

FAirclough Norman (1989). Language and Power. Harlow: Longman.

FAIRClough Norman (2012). Critical discourse analysis. International Advances in Engineering and Technology 7, 452-487.

Halberstam, Judith (2001). Telling tales: Brandon Teena, Billy Tipton, and transgender biography. In Maria C. SAnchez, Linda Schlossberg (eds.), Passing: Identity and Interpretation in Sexuality, Race, and Religion, 13-37. New York, NY: New York University Press.

Hall Stuart (1997). The spectacle of the “Other." In Cultural Representations and Signifying Practices, Stuart Hall (ed.), 223-290. London: SAGE/Open University.

Hord Levi C.R. (2016). Bucking the linguistic binary: Gender neutral language in English, Swedish, French, and German. Western Papers in Linguistics/Cahiers linguistiques de Western: Vol. 3(1), Article 4.

Huang Ni, Hong Yili, Burtch Gordon (2015). Anonymity and language usage: A natural experiment of social network integration. Paper presented at the Thirty Sixth International Conference on Information Systems, Fort Worth. [URL: https://pdfs.semanticscholar.org/f75a/6cb2ac51f40e11a78a464d14e2ad0de468be. pdf; accessed March 22, 2019].

Jørgensen Marianne W., Phillips Louise J. (eds.) (2002). Discourse Analysis as Theory and Method. London: SAGE Publications.

Livia Anna, Hall Kira (1997). "It's a girl!": Bringing performativity back to linguistics. In Queerly Phrased. Language, Gender, and Sexuality, Anna Livia, Kira Hall (eds.), 3-18. New York, Oxford: Oxford University Press.

Motschenbacher Heiko, Stegu Martin (2013). Introduction: Queer Linguistics approaches to discourse. Discourse \& Society 24, 519-535.

Thurlow Crispin, Lengel Laura, Tomic Alice (2004). Computer Mediated Communication. Social Interaction and the Internet. London, Thousand Oaks, New Delhi: SAGE.

Wernick Laura J., Kulick Alex, Inglehart Marita H. (2014). Influences of peers, teachers and climate on students' willingness to intervene when witnessing antitransgender harassment. Journal of Adolescence 37(6), 927-935.

\section{Internet sources}

Allen Samantha (2017). The political pettiness of misgendering transgender people. The Daily Beast.

[https://www.thedailybeast.com/this-is-why-misgendering-hurts-transgender-people-so-much; accessed March 24, 2019]. 
Anderson Ryan T. (2018). Transgender ideology is riddled with contradictions. Here are the big ones. The Heritage Foundation.

[https://www.heritage.org/gender/commentary/transgender-ideology-riddled-contradictions-here-are-the-big-ones; accessed May 21, 2019].

BAILEY Emma (2012). Behaviour that's transphobic and why. Wipe Out Transphobia. [http://www.wipeouttransphobia.com/2012/07/20/transgender-suicide-rate/; accessed May 29, 2019].

Bartram Fay (nd.). Ten steps to tackling homophobic, biphobic and transphobic language in your school.

[http://www.stonewall.org.uk/sites/default/files/hbt_language.pdf; accessed February 8, 2018].

Beaumont-Thomas Ben (2016). Anohni, the artist once known as Antony Hegarty, on life beyond the Johnsons. The Guardian.

[https://www.theguardian.com/music/2016/apr/09/trans-singer-anohni-new-albumhopelessness; accessed March 21, 2019].

Butler Tijen (2018, December 4). Deadname: What is deadnaming and who is guilty of it? PinkNews.

[https://www.pinknews.co.uk/2018/12/04/deadname-deadnaming/; accessed March 25, 2019].

Chiu Allyson (2018, August 14). Laverne Cox lambastes 'deadnaming.' What is it and why is it a problem? The Washington Post.

[https://www.washingtonpost.com/news/morning-mix/wp/2018/08/14/laverne-coxlambastes-deadnaming-what-is-it-and-why-is-it-a-problem/; accessed March 22, 2019].

Clements KC (nd.). What does it mean to misgender someone? Healthline.

[https://www.healthline.com/health/transgender/misgendering; accessed March 21, 2019].

Clements KC (2017, October 19). What is deadnaming? Healthline.

[https://www.healthline.com/health/transgender/deadnaming; accessed March 21, 2019].

Cox Laverne (nd.). Laverne's story...

[https://lavernecox.com/about/; accessed May 17, 2019].

DyNARski Wiktor (ed.) (2016). “To nie są żadne chore fantazje.” Osoby transpłciowe wobec prac parlamentu nad ustawą o uzgodnieniu płci.

[http://transfuzja.org/download/publikacje/fatazje2016compressed.pdf; accessed February 8, 2018].

DyNARski Wiktor, JĄDEREK Izabela, KŁonkowska Anna M. (eds.) (2016). Transpłciowa młodzież w polskiej szkole. Raport $\mathrm{z}$ badań.

[http://transfuzja.org/download/publikacje/transplciowa_mlodziez.pdf; accessed February 8, 2018].

Dennis Riley J. (2017). Misgendering trans people is an act of violence | Riley J. Dennis [https://www.youtube.com/watch?v=g-u5gYxXHoA; accessed March 20, 2019].

Ferguson, Sian. (2014). 3 examples of everyday cissexism. Everyday Feminism. [https://everydayfeminism.com/2014/03/everyday-cissexism/; accessed May 25, 2019].

Hall Francesca (2015). Getting Started. A toolkit for preventing and tackling homophobic, biphobic and transphobic bullying in secondary schools. 
[http://www.stonewall.org.uk/sites/default/files/getting_started_a_toolkit_for_secondary_schools.pdf; accessed February 8, 2018].

HaAs Ann P., Rodgers Philip L., Herman Jody L. (2014). Suicide attempts among transgender and gender non-conforming adults.

[https://williamsinstitute.law.ucla.edu/wp-content/uploads/AFSP-Williams-SuicideReport-Final.pdf; accessed February 7, 2018].

Hamann Christopher C. (2014). Trans enough: trans/gender identities and (mis)representation in social work.

[http://scholarworks.smith.edu/cgi/viewcontent.cgi? article=1876\&context $=$ theses; accessed February 5, 2018].

Hope Sam (2014). Please use my pronouns! A feminist challenging transphobia.

[https://feministchallengingtransphobia.wordpress.com/2014/07/09/please-use-mypronouns/; accessed May 29, 2019].

Kondracki Jerzy A., Davies Norman, Hutchinson Dawson Andrew, Jasiewicz Krzysztof, Smogorzewski Kazimierz Maciej, Roos Hans, Wandycz Piotr S. (2019). Poland. In Encyclopeedia Britannica online.

[https://www.britannica.com/place/Poland/Government-and-society; accessed March 23, 2019].

LubNauer Katarzyna (2015). Senat - czy to się leczy farmakologicznie? Liberté!

[https://liberte.pl/senat-czy-to-sie-leczy-farmakologicznie/; accessed May 20, 2019].

Pareles Jon (2016). Anohni: Embracing a new name, and sound. The New York Times.

[https://www.nytimes.com/2016/04/24/arts/music/anohni-embracing-a-new-nameand-sound.html; accessed March 21, 2019].

PavlíčEK Antonín (2005). Anonymity on the internet and its influence on the communication process. Prague: Charles University. PhD dissertation [accessed December 23, 2018].

Reynolds Daniel (2016). Meet the second-ever transgender Oscar nominee. The Advocate.

[https://www.advocate.com/film/2016/1/14/meet-second-transgender-oscar-nominee; accessed March 21, 2019].

ST. PAtrick Joli (2017). What you're really saying when you misgender. The Body Is Not an Apology.

[https://thebodyisnotanapology.com/magazine/what-youre-really-saying-when-youmisgender/; accessed March 23, 2019].

SzewCZyк Paula (2017). “Jestem gejem i homofobem”. Niemożliwe? Newsweek Polska.

[https://www.newsweek.pl/polska/spoleczenstwo/homofobia-oraz-transfobiawewnatrz-srodowiska-lgbt/1shc23c; accessed March 22, 2019].

Talusan Meredith (2015, April 2). Being transgender in a transphobic society leads to moments of sheer desperation. The Guardian.

[https://www.theguardian.com/commentisfree/2015/apr/02/being-transgender-in-atransphobic-society-leads-to-moments-of-sheer-desperation; accessed November $11,2018]$.

Turner Lewis, Whittle Stephen, Combs Ryan (2009). Transphobic Crime in the European Union. London: Press For Change [accessed March 23, 2019].

WASIAK-RAdoszewski Aleksander (nd.). Transfobia. RÓWNOŚĆ.INFO. [https:// rownosc.info/dictionary/transfobia/; accessed March 23, 2019]. 
Magdalena Derecka

Instytut Filologii Angielskiej

Wydział Filologiczny

Uniwersytet Jagielloński

ul. Gołębia 24

31-007 Kraków

magdalena.derecka(at)student.uj.edu.pl 
